\title{
The best athletes are better
}

SIR - The pre-Olympic Briefing ${ }^{1}$ was fascinating reading. Indeed, it gave a good insight into the problems and promises of training for élite sports participation and success. But I found some of the statements in "Science tracks down the training dangers" unjustified. It is true that the media portrays élite sports and intensive training in young athletes as potentially dangerous. Given the relative immaturity of a young athlete's skeletal system, bones are at risk of injuries that could result in long-term deleterious consequences ${ }^{2}$. The irresponsibly high level of training and the will of parents to have an élite sporting child are especially dangerous in the production of both acute and overuse injuries. To clarify the effects of intensive training on young athletes, nearly a decade ago the Sports Council financed a mixed longitudinal study to examine the issue. The study, named TOYA (Training of Young Athletes), recruited a sample of 453 children already at the top for their age groups ( 9 to 17 years of age at the beginning of the study) in their respective sports (football, gymnastics, swimming and tennis) and followed them for three years.

The TOYA team, based at the Institute of Child Health in London, and of which I was the Medical Officer, was expecting a significant number of injuries in these children. The surprising finding was that in this cohort of élite, intensively trained young athletes in physically demanding sports, each athlete was injured on average only once a year for the whole duration of the study ${ }^{3,4}$. There were no significant differences to be ascribed to chronological or biological age, velocity of growth, or intensity or length of training ${ }^{4}$. On the other hand, club players of the same age trying to reach the élite status (but not enrolled in the TOYA study) were experiencing serious injuries, requiring them to abandon their sport at a relatively early age ${ }^{5}$.

The TOYA team believes that, while the risk of injury is present in any sport, especially if practised at high level, the élite children entering the study were 'musculoskeletally' gifted, and their musculoskeletal system, either through training or genetically, is more able to withstand the stresses of the intensive training needed to reach the élite status and to stay there. The less musculo-skeletally gifted children and their coaches, trying, by emulation of the same training routines, to reach the 'élite'

\footnotetext{
1. Nature 382, 12-16 (1996).

. Maffulli, N. Sports Med 9, 229-243 (1990).

3. Baxler-Jones, A., Maffulli, N. \& Helms, P. Arch. Dis. Baxler-Jones, A., Maffulli, N.
Child. 68, 130-132 (1993).

4. Maffulli, N., King, J. B. \& Helms, P. Br. J. Sports Med. 28, 123-136 (1994).

5. Maffulli, N., Chan, D. \& Aldridge, M. J. J. Pediatr. Orthopaed. 12, 344-350 (1992).
}

status, impose on their musculo-skeletal system stresses which, eventually, result in overuse injuries.

In the end, high-level training is not good for some, but some children are able to withstand the rigours that top-level sport entails. At present, however, there is no secure way of identifying children whose musculoskeletal system can stand intensive training, and we have to learn how much is enough from observing how much is too much.

\section{Nicola Maffulli}

Department of Orthopaedic Surgery, University of Aberdeen Medical School, Polwarth Building, Foresterhill, Aberdeen AB9 2ZD, UK

\section{Greek needs}

SIR - Current thinking on the future research targets of the European Union (EU) apparently revolves around 'topdown' directives (see Nature 381, 631, 634 \& 635; 1996). Although this approach is essential for the management of megaprojects with technically visible goals (such as the yeast genome project or highdefinition television), it can lead in the long term to asphyxiation of innovative drive. What data support the notion that 'proxy customers' can have a clear perception of the 'products' they will need 10 years down the line? Who among the people in Brussels can predict which plan or bacterial biochemical will produce a future antibiotic? It was not the wishes and visions of endusers or think-tanks that brought about the personal computer revolution, the personal stereo or the World Wide Web. The US biotechnology industry did not blossom because of federal government inspiration.

Wealthier EU members will be well advised to continue supporting fundamental research. Forcing European research to become more 'applied' and 'productoriented' seems more a cure for the symptoms than for the underlying causes of poor industrial innovation. Of course EU academics must become more aware of the marketplace and develop entrepreneurial thinking and links to corporate Europe. Admittedly, a lot of time and money is lost preparing all these EU collaborative grant applications, but Brussels should seriously consider the introduction of informatics tools to aid submission, refereeing and assessment of research applications. The scientific community is already using the Internet to put proposals together in electronic form before sending printouts to Brussels.

Discussion of the 'cohesion' aspects of the new EU Framework programme should not stem from the assumption that the inhabitants of less developed EU regions have a genetic predisposition to poor academic performance. This idea will not go down well with the hundreds of young Greeks, Spaniards and Portuguese who are burning the midnight oil in many of the centres of excellence of the North. What the EU should do, instead, is to support the most promising among these young scientists upon their repatriation with 'return grants' not for 12 months (as now) but for five years. Such grants could be administered by the European Molecular Biology Organization, which has gained valuable experience from its outstanding postdoctoral programme.

EU financial support has been instrumental in catalysing and maintaining new research in the 'less favoured' regions of the EU. Establishments such as the Institute of Molecular Biology and Biotechnology in Crete have demonstrated a remarkable ability to carry out research of international calibre and to earn competitive grants, and have trained graduate students and postdoctoral fellows from other EU countries. Such centres have now started attracting reinforcements from the vast pool of expatriate Greek scientists (approximately 6,000 PhDs in the United States; 300 university professors in the Boston area alone). Without EU help, the brain-drain to the United States (where, incidentally, California does not team up with Massachusetts to form élite clubs seeking dominance over Montana) is bound to continue.

Young Greek scientists do not seek charity. We do, however, ask for assistance to grow. Despite admirable efforts by the Hellenic Research Secretariat, we find it hard to get assistance from a government that is forced to maintain the highest defence spending among NATO (North Atlantic Treaty Organization) countries (4.6 per cent of gross national product).

We believe that EU funds should nourish only scientific excellence, overriding the usual politicking that is rife throughout the Old World (and not just on its periphery). And we, in a 'less favoured' region, can carry out good research and achieve technological breakthroughs. Should we be penalized for being successful? Young Greeks, like other young Europeans, have been brought up to believe in the social engineering vision of a community of European states. We are determined to be part of our common tomorrow and to help shape it. We have a lot to offer European science besides memorable holidays.

Tassos Economou

Institute of Molecular Biology

and Biotechnology,

Foundation of Research

and Technology-Hellas,

PO Box 1471, Iraklio,

Crete, Greece

e-mail: aeconomou@nefeli.imbb.forth.gr 